\title{
Relacje Unii Europejskiej i państw regionu Azji Centralnej w obliczu kryzysu stosunków turecko-unijnych
}

\section{Wprowadzenie}

W przeciwieństwie do Unii Europejskiej, dla Republiki Turcji Azja Centralna tradycyjnie stanowi przedmiot zainteresowania. Przyczyną tego są w pierwszej kolejności silne więzi kulturowe, religijne, językowe, etniczne oraz historyczne z narodami zamieszkującymi ten region. Znaczący rozwój wzajemnej współpracy pomiędzy Turcją a państwami tego obszaru nastąpił w oczywisty sposób już na początku lat dziewięćdziesiątych ubiegłego wieku. Jednocześnie dojście do władzy w 2002 roku proislamskiej Partii Sprawiedliwości i Rozwoju (tur. Adalet ve Kalkınma Partisi, AKP), stanowiło początek istotnych przemian wewnętrznych w Turcji, których konsekwencje dostrzegalne są także współcześnie oraz mają swoje wymierne przełożenie na politykę zagraniczną tego państwa - objęcie sterów władzy przez stronnictwo Recepa Tayyipa Erdoğana wprowadziło nową dynamikę aktywności międzynarodowej tego kraju przy wykorzystaniu szeregu instrumentów gospodarczych oraz dyplomatycznych. Dostrzegalny był bezprecedensowy wzrost aktywności Ankary na arenie międzynarodowej, oparty w znacznej mierze o zasady nowego paradygmatu polityki zagranicznej tj. koncepcji ,strategicznej głębi” opracowanej przez Ahmeta Davutoğlu (Davutoğlu, 2001). W chwili obecnej relacje Turcji z Unią Europejską ulegają konsekwentnemu pogarszaniu się. Jednocześnie międzynarodowym działaniom Turcji towarzyszy intensyfikacja kontaktów oraz wieloraka aktywność w różnych regionach świata, a także swoistego rodzaju jednostajny odwrót od europejskiej integracji, jako odwiecznego celu kolejnych tureckich rządów i przywódców. W tym kontekście Azja Centralna stanowi istotny przedmiot zainteresowania Ankary, aczkolwiek nie o priorytetowym charakterze. Należy w tym miejscu zwrócić uwagę, że także dla samej Unii Europejskiej kryzys w stosunkach z Turcją może mieć swoje wielorakie konsekwencje, a waga wzajemnych relacji najprawdopodobniej przyczyni się do wypracowania w najbliższej przyszłości nowego modelu instytucjonalnej i przedmiotowej współpracy obu podmiotów. Taki stan rzeczy otwartym czyni pytanie o to czy stosunki Unii Europejskiej z państwami Azji Centralnej zyskają nową dynamikę? Tym samym celem niniejszego artykułu jest rozstrzygnięcie kwestii czy spadek znaczenia Turcji jako partnera dla Wspólnoty przełoży się na automatyczny wzrost znaczenia wspomnianego regionu świata dla Unii Europejskiej. W toku wywodu omówiona zostanie także w zarysie historia wzajemnych relacji oraz ich dotychczasowa dynamika. 


\section{Zarys relacji Unii Europejskiej z państwami Azji Centralnej}

Obszar Azji Centralnej przez długi okres swojej historii pozostawał poza politycznym i gospodarczym zainteresowaniem państw Unii Europejskiej. Do początku lat dziewięćdziesiątych był on częścią Związku Radzieckiego i jako taki nie stanowił samodzielnej przestrzeni politycznej, istotnej z perspektywy polityki międzynarodowej, postrzegany był raczej jako swoistego rodzaju „terra incognito" (Özalp, 2011, s. 17).

Upadek ZSRR oraz powstanie na tym obszarze szeregu niepodległych państw takich jak Kazachstan, Uzbekistan, Turkmenistan, Kirgistan oraz Tadżykistan, zmieniło sytuację międzynarodową oraz wymusiło konieczność zajęcia przez Unię Europejską stanowiska wobec tak całego regionu, jak i poszczególnych państw tego obszaru. Należy w tym miejscu podkreślić, że początek lat dziewięćdziesiątych nie stanowił w tym kontekście znaczącego przełomu, a stanowisko UE w tym okresie może zostać określone jako niezdecydowane, gdzie nie podjęto w zasadzie konkretnych inicjatyw politycznych (Melwin, 2008, s. 2). Przyczyną tego stanu rzeczy była zarówno złożona sytuacja polityczna i gospodarcza państw regionu oraz problemy wewnątrz samej Unii Europejskiej, dla której początek ostatniej dekady ubiegłego wieku oznaczał konieczność sprostania szeregowi wyzwań, takich jak chociażby problem zjednoczenia Niemiec, skomplikowana sytuacja polityczna i gospodarcza Europy ŚrodkowoWschodniej, kwestia dalszego rozszerzenia Unii oraz konieczność przeprowadzania istotnych reform wewnętrznych. Wszystkie te elementy sprawiły, że UE w początkowym okresie nie wypracowała jednolitej polityki wobec Azji Centralnej (Erdoğan, 2011, s. 13-15). Dodatkowo państwa regionu doświadczyły potężnych problemów ekonomicznych związanych z gwałtownym odejściem od systemu centralnie planowanej gospodarki oraz załamaniem się tradycyjnego rynku eksportu do Związku Radzieckiego. W relatywnie krótkim okresie doprowadziło to do spadku stopy życiowej oraz pogłębienia się nierówności ekonomicznych (Pomfret, 2006, s. 1).

Jednocześnie brakowi konkretnego zaangażowania politycznego $\mathrm{w}$ regionie towarzyszyła zakrojona na szeroką skalę pomoc rozwojowa udzielana poszczególnym państwom. W latach 1991-2001 jej całkowita wartość wyniosła 944,4 miliona euro, z czego 366,3 miliona przekazano w ramach Programu Pomocy Technicznej dla Wspólnoty Niepodległych Państw (TACIS), którego intencją było wspieranie reform demokratycznych i prorynkowych. W ramach TACIS przekazano łącznie 118,2 miliona euro dla Uzbekistanu, 134,6 miliona dla Kazachstanu, 63,2 miliona dla Kirgistanu, 42,3 miliona dla Turkmenistanu oraz 8 milionów euro dla Tadżykistanu (European Union External Action, 2002, s. 36-37). Obok programu TACIS uruchomiono także inne narzędzia pomocowe; do roku 2001 przekazano 153,5 miliona euro Tadżykistanowi i Kirgistanowi w ramach pomocy Dyrekcji Generalnej Komisji Europejskiej ds. Pomocy Humanitarnej i Ochrony Ludności (ECHO), zaś ze środków samej Komisji Europejskiej pięciu państwom przyznano łącznie 279,7 miliona euro (European Union External Action, 2002, s. 36-37).

Początek obecnego wieku znamionował modyfikację polityki zagranicznej Unii Europejskiej wobec regionu. O ile w poprzednim okresie Azja Centralna nie stanowiła punktu uwagi unijnych przywódców w sytuacji niewielu wspólnych interesów (Wallas, 2006, s. 5; Warkotsch, 2011, s. 4), to wydarzenia polityki światowej początku stulecia 
zmieniły ten stan rzeczy. Kluczową kwestią był zamach z 11 września 2001 roku oraz początek globalnej wojny z terroryzmem. Mająca wkrótce miejsce interwencja państw zachodnich w Afganistanie uczyniła region niezwykle istotnym w kontekście geostrategicznym, czego dowodem było utworzenie w Uzbekistanie i Kirgistanie baz wojskowych Międzynarodowych Sił Wsparcia Bezpieczeństwa, a sam region niejako otworzył się na wpływy państw zewnętrznych (Kurecic, 2010, s. 23). Także w ramach samej UE dostrzeżono konieczność głębszego zaangażowania się w sprawy Azji Centralnej, głównie za sprawą presji ekonomicznej dziesięciu nowych państw członkowskich (od 2004 roku), wzrastającego zapotrzebowania na energię związanego z koniecznością zapewnienia dostaw surowców oraz szeroko rozumianego bezpieczeństwa (Pohl, 2016, s. 46).

Należy zwrócić uwagę, że od 2001 r. widoczny jest zarówno wzrost kontaktów politycznych UE z państwami regionu przy jednoczesnym zachowaniu ciągłości udzielanej pomocy rozwojowej, mającej na celu także stymulację procesów demokratycznych w państwach Azji Centralnej.

Już w 1994 roku ustanowiono Przedstawicielstwo Komisji Europejskiej w Kazachstanie (w Ałmaty). W 2004 roku uruchomiono w Biszkeku i Duszanbe działalność dwóch izb podlegających bezpośrednio jednostce w Kazachstanie, a w 2010 roku podniesiono ich status do rangi osobnych Przedstawicielstw Komisji Europejskiej. W 2011 roku otwarto Przedstawicielstwo w Uzbekistanie. W 2005 roku ustanowiono pierwszego Specjalnego Przedstawiciela Unii Europejskiej w Azji Centralnej, którym został słowacki dyplomata Jan Kubiš (Przybylska-Maszner, 2016, s. 356). Zadaniem Przedstawiciela jest szeroko rozumiana koordynacja relacji UE ze stosownym regionem oraz wsparcie działalności Wysokiego Przedstawiciela Unii do Spraw Zagranicznych oraz Polityki Bezpieczeństwa. Od 2015 roku funkcję tę pełni, także pochodzący ze Słowacji, Peter Burian.

Kluczowym momentem wzajemnych relacji było przyjęcie w 2007 przez UE dokumentu „Unia Europejska i Azja Centralna: Strategia dla Nowego Partnerstwa”. Strategia wskazuje kluczowe obszary, które mogą stanowić pole wymiany doświadczeń EU i państw regionu, takie jak demokratyzacja, edukacja, rządy prawa, prawa człowieka, kwestie energetyczne oraz wymiana handlowa. Strategia była modyfikowana w latach 2008, 2010, 2012 i 2015, ale jej podstawowe założenia pozostają niezmienne, a podstawowym celem pozostaje wzmocnienie współpracy UE oraz państw regionu, ze szczególnym uwzględnieniem, obok już wspomnianych, takich elementów jak bezpieczeństwo, transport, edukacja. W 2009 roku określono kluczowe inicjatywy mające wzmocnić obecność UE na tym obszarze. Były to: ustanowienie regularnego dialogu politycznego na poziomie ministerstw zagranicznych, utworzenie Europejskiej Inicjatywy Edukacyjnej i wsparcie państw Azji Centralnej w rozwoju „e-jedwabnego szlaku”, utworzenie Inicjatywy Rządów Prawa, zaangażowanie w regularny, ukierunkowany na osiągnięcie rezultatów dialog w kwestii praw człowieka z każdym z pięciu państw oraz ustanowienie regularnego dialogu w sprawach energii z krajami tego obszaru (EU and Central Asia: Strategy for New Partnership, 2009, s. 11).

W dalszym ciągu UE kontynuowała udzielanie państwom regionu pomocy rozwojowej. Od 2007 roku podstawowym narzędziem pomocowym jest Instrument Finansowania Współpracy na rzecz Rozwoju; w sposób bardziej szczegółowy charakter wsparcia określają trzy podstawowe dokumenty. 
Pierwszym jest Dokument Strategii Regionalnej o Pomocy dla Azji Centralnej na lata 2007-2013. Łączny przewidziany budżet pomocowy wynosił 719 milionów euro, a podstawowy cel określono jako: ,promowanie stabilności i bezpieczeństwa państw Azji Centralnej, pomoc w dążeniu do zrównoważonego rozwoju ekonomicznego, redukcja ubóstwa i wzmocnienie współpracy regionalnej, zarówno w samej Azji Centralnej, jak i pomiędzy regionem a Unią Europejską" (Regional Strategy Paper for Assistance to Central Asia for the Period 2007-2013, 2007, s. 3). Kolejne dwa dokumenty to Programy Wskazujące na lata 2007-2010 oraz 2011-2013. W pierwszym przypadku przyznano kwotę 314 miliona euro (78,5 miliona rocznie), zaś w drugim widoczne było zwiększenie budżetu do 321 milionów euro (107 miliona rocznie).

Najnowszą inicjatywą pomocową jest ,Wieloletni Program Wskazujący dla Azji Centralnej na lata 2014-2020". Całościowy budżet Programu wynosi 360 milionów euro, gdzie 170 milionów przeznaczono na wsparcie zrównoważonego rozwoju regionalnego, $37,5 \mathrm{mln}$ euro na wzmocnienie bezpieczeństwa regionalnego, $35 \mathrm{mln}$ na pomoc techniczną, zaś 115 milionów na rozwój mobilności studentów w ramach Programu Erasmus+ (Multiannual Indicative Programme Regional Central Asia 2014-2020, 2014, s. 6).

Podsumowując należy zwrócić uwagę, że stosunki Unii Europejskiej z państwami regionu Azji Centralnej ewoluowały w istotny sposób. Początkowo, w latach dziewięćdziesiątych ubiegłego wieku, nie miały one stricte politycznego charakteru, a jedynie ograniczały się do, skądinąd chętnie przyjmowanej, pomocy rozwojowej ze strony UE. Zmieniająca się sytuacja polityczna świata początku obecnego stulecia uczyniła z obszaru Azji Centralnej ważny element polityki zagranicznej Unii, aczkolwiek kwestie jej priorytetów i realnych możliwości pozostają mocno problematyczne.

\section{Unia Europejska a Azja Centralna - priorytety i ograniczenia}

Przyjęcie w 2007 roku „Strategii dla Nowego Partnerstwa” zbiegło się w czasie z kryzysem dostaw rosyjskiego gazu na teren Ukrainy oraz szeregu państw Unii Europejskiej. Tym samym konieczność dywersyfikacji źródeł energii stała się swoistego rodzaju priorytetem dla UE. W tym kontekście region Azji Centralnej i jego zasoby, nabierają szczególnego znaczenia, co zostało jednoznacznie podkreślone w 2007 roku: „Wzrastająca zależność państw członkowskich UE od zewnętrznych źródeł energii oraz zapewnienie bezpieczeństwa dostaw są punktem specjalnej uwagi Unii Europejskiej. Azja Centralna, ze swoimi istotnymi zasobami węglowodorów oraz dogodnym dla transportu na rynki europejskie położeniem geograficznym, odgrywać będzie ważną rolę w zapewnieniu dostaw surowców energetycznych dla UE. Obok Rosji, Kazachstan, Turkmenistan i Uzbekistan posiadają drugie największe na świecie rezerwy ropy naftowej i gazu [...] Wyzwaniem dla UE i jej partnerów w Azji Centralnej jest rozwój wzajemnie korzystnego dialogu producentów surowców, państw tranzytowych i konsumentów, tak na poziome bilateralnym, jak i regionalnym. Stosunki z głównymi producentami, Kazachstanem i Turkmenistanem, muszą ulec poprawie" (Regional Strategy Paper for Assistance to Central Asia for the Period 2007-2013, 2007, s. 5-6). Tym samym współpraca w sektorze energetycznym stanowi priorytet dla EU. Cele polityczne wydają się podporządkowane realizacji wspomnianego zamierzenia, a sama Unia 
zmierza do: „konwergencji rynków energetycznych poprzez harmonizację istotnego ustawodawstwa i ram regulacyjnych, wzmocnienia bezpieczeństwa energetycznego państw Azji Centralnej i UE poprzez bliższą współpracę, wsparcia zrównoważonego rozwoju energetycznego łącznie z poprawą wydajności energetycznej oraz rozwojem sektora energii odnawialnej, a także przyciągania inwestycji w projekty energetyczne wspólnego i regionalnego znaczenia" (EC External Relations, 2014, s. 1).

Bez wątpienia kwestia zaopatrzenia Europy w dostawy surowców energetycznych z Azji Centralnej, ma dla UE znaczenie priorytetowe w procesie kształtowania całościowej polityki wobec tego obszaru, co stanowi jednocześnie o jej istotnych ograniczeniach.

Należy w tym miejscu zwrócić uwagę, że państwa tego regionu zmagają się z jednej strony, z silnym dziedzictwem długotrwałych rządów niedemokratycznych (Fiedler, 2016, s. 375), z drugiej zaś, muszą w swojej polityce zagranicznej uwzględniać interesy takich mocarstw jak Federacja Rosyjska oraz Chiny, które także istotnie są zaangażowane w sprawy Azji Centralnej (Osiewicz, 2016, s. 175). W tym kontekście aktywność Unii Europejskiej może być problematyczna, a pragmatyczne interesy wymiany handlowej (przede wszystkim w sektorze źródeł energii) będą przysłaniały pozostałe cele, wielokrotnie artykułowane we wspomnianych unijnych dokumentach.

Państwa regionu mają świadomość, że dla Unii Europejskiej kwestia bezpieczeństwa dostaw surowców energetycznych ma znaczenie priorytetowe (Peyrouse, 2014, s. 6). Dodatkowo problematyczna jest percepcja samej Unii w Azji Centralnej, gdzie z jednej strony, występuje zjawisko niechęci elit politycznych wobec swoistego rodzaju narzucania wartości liberalnych i demokratycznych, z drugiej zaś, niejednokrotnie dochodzi do sytuacji, w której UE nie przedstawia jednorodnego stanowiska, a decydujące znaczenie ma głos poszczególnych państw członkowskich (Peyrouse, 2014, s. 5-6). Taka postawa stoi w sprzeczności z działaniami istotnych aktorów obszaru Azji Centralnej tj. Federacji Rosyjskiej oraz Chin, które udzielają państwom regionu bezwarunkowego wsparcia, przeciwnie niż UE (Walkowski, 2016, s. 97). Ponadto należy zwrócić uwagę, że poradzieckie republiki posiadają specyficzną kulturę polityczną, która tak naprawdę bliższa jest swoim odpowiednikom w Rosji oraz Chinach, niż w poszczególnych państwach Unii Europejskiej (Zhao, 2006). Wymienione czynniki sprawiają, że kontekście braku ambicji UE do odgrywania aktywnej roli w innych obszarach niż sektor energetyczny (jak chociażby bezpieczeństwo czy też wzrost wymiany handlowej innych sektorów), ograniczonych możliwościach oraz silnej rywalizacji z innymi graczami, UE napotyka na szereg ograniczeń swoich działań, a jej potencjał jest w zdecydowany sposób niewykorzystany.

\section{Podsumowanie}

Dziesięć lat po przyjęciu Strategii dla Nowego Partnerstwa Rada Unii Europejskiej dokonała podsumowania tego okresu. W przyjętej rezolucji podkreślono, że państwa tego regionu stały się ważnymi partnerami Unii, a osiągnięte postępy uznano za zadowalające. Jednocześnie zwrócono uwagę, że takie dziedziny jak funkcjonowanie praw człowieka, edukacja, zrównoważony rozwój oraz szereg nowych zagrożeń w sferze 
bezpieczeństwa, wymagają w dalszym ciągu zacieśnienia relacji oraz dialogu. Do końca 2019 roku ma zostać przedstawiony wniosek w sprawie nowej strategii, dopasowanej do globalnej strategii całej UE (Council of the European Union, 2017, s. 1-6).

Uwagę zwraca fakt, że kluczowe z punktu widzenia unijnego soft power zagadnienia, jak prawa człowieka oraz edukacja, w dalszym ciągu wymagają znacznych nakładów i wysiłku.

Należy w tym miejscu podkreślić wyraźną ewolucję polityki Unii Europejskiej wobec Azji Centralnej. W latach dziewięćdziesiątych w pierwszej kolejności ograniczała się ona do zakrojonej na szeroką skalę pomocy rozwojowej. W XXI wieku, wraz ze zmianami w środowisku międzynarodowym oraz szeregiem problemów sfery bezpieczeństwa (przede wszystkim energetycznego) UE podjęła wysiłek wypracowania wspólnej strategii politycznej wobec wspomnianego obszaru. W chwili obecnej ważkie wydarzenia w sąsiedztwie UE otwartym czynią pytanie o przyszły charakter wzajemnych relacji.

Aktualnie pierwszoplanowego znaczenia nabiera przyszłość kontaktów Unii Europejskiej i Republiki Turcji. Dynamiczna sytuacja wewnętrzna tej ostatniej, wraz ze znaczącym wzrostem tendencji autorytarnych prezydenta Recepa Tayyipa Erdoğana, doprowadziły w praktyce do zamrożenia negocjacji odnośnie ewentualnego członkostwa Turcji w tej organizacji oraz ogólnego kryzysu bezpośrednich kontaktów, także o bilateralnym charakterze.

W tym kontekście zasadne jest pytanie, o to czy relacje z państwami Azji Centralnej mogą stać się priorytetowe dla UE w sytuacji dalszego osłabienia instytucjonalnych więzi z Turcją. Można stwierdzić, że w chwili obecnej nie istnieją rzeczywiste przesłanki uzasadniające takie stwierdzenie.

Szczególnego znaczenia nabiera w tym kontekście realna możliwość wywierania wpływu na procesy polityczne wewnątrz państw Azji Centralnej przez Unię Europejską. Jest ona mocno ograniczona, albowiem elity polityczne tych państw, wywodzące się niejednokrotnie wprost $\mathrm{z}$ dawnego komunistycznego aparatu władzy, pozostają niechętne otwarciu się na demokratyczne ideały i propozycje UE.

Kolejną istotną sprawą jest znaczenie samej Unii Europejskiej dla Turcji oraz państw Azji Centralnej. Należy podkreślić, że UE w dalszym ciągu pozostaje najważniejszym partnerem handlowym Ankary. W tej sytuacji nie należy spodziewać się całkowitego zerwania relacji pomiędzy zainteresowanymi podmiotami. Sprawa integracji i percepcja Europy najpewniej będą w dalszym ciągu instrumentalnie wykorzystywane w polityce wewnętrznej Turcji przez R. T. Erdoğana, ale jego polityka zagraniczna z pewnością będzie uwzględniać czynnik unijny. Z kolei państwa Azji Centralnej posiadają realne alternatywy zbytu swoich surowców, co więcej, to właśnie one posiadają w tym zakresie przewagę, ponieważ są, w odróżnieniu od Turcji, eksporterami kluczowych dla UE surowców energetycznych.

Rekapitulując należy stwierdzić, że w najbliższej przyszłości obszar Azji Centralnej pozostanie dla UE ważny w kontekście zapewnienia bezpieczeństwa energetycznego Europy. W dalszym ciągu Bruksela będzie podejmować inicjatywy związane z takimi obszarami przedmiotowymi jak edukacja, demokratyzacja, prawa człowieka, ale bez wątpienia to wspomniana wyżej kwestia będzie miała priorytetowy charakter. Tym samym, pozostające w geograficznym i politycznym oddaleniu od UE państwa 
Azji Centralnej, podlegać będą pragmatycznej logice wymiany handlowej, nie będąc w stanie jednocześnie wypełnić politycznej luki po coraz bardziej oddalającej się od wartości i struktur unijnych Turcji.

\section{Bibliografia}

Council of the European Union (2017), Outcome of Proceedings, http://www.consilium.europa.eu/ media/23991/st10387en17-conclusions-on-the-eu-strategy-for-central-asia.pdf.

Davutoğlu A. (2001), Stratejik Derinlik. Türkiye'nin uluslararası konumu, İstanbul.

EC External Relations (2014), Energy, Central Asia and the European Union, http://eeas.europa.eu/ archives/docs/central_asia/docs/factsheet_energy_en.pdf.

Erdoğan M. M. (2011), Türk Cumhuriyetleri'nin Bă̆ımsızlıklarının 20. Yılında Avrupa Birliği'nin Orta Asya Politikaları Raporu, Ankara.

EU and Central Asia: Strategy for New Partnership (2009), http://www.consilium.europa.eu/ media/30828/en-strategyasia_int.pdf.

European Union External Action (2002), Strategy Paper 2002-2002 \& Indicative Programme 2002-2004 for Central Asia, http://eeas.europa.eu/archives/docs/central_asia/rsp/02_06_en. pdf.

Fiedler R. (2016), Unia Europejska na rzecz demokratyzacji państw Azji Centralnej - działania i efekty, „Rocznik Integracji Europejskiej”, nr 10.

Kurecic P. (2010), The New Great Game: Rivalry of Geostrategies and Geoeconomies in Central Asia, "Hrvatski Geografski Glasnik", 72/1.

Melwin N. J. (2008), Introduction, w: Engaging Central Asia: The European Union's New Strategy in the Heart of Eurasia, ed. N. J. Melwin, Brussels.

Multiannual Indicative Programme Central Asia 2014-2020 (2014), https://ec.europa.eu/europeaid/ sites/devco/files/mip-2014-2020-central-asia-regional-20140812-en.pdf.

Osiewicz P. (2016), Udziat państw Azji Centralnej w Szanghajskiej Organizacji Wspótpracy. Wnioski dla Unii Europejskiej, w: Unia Europejska wobec Azji Centralnej - uwarunkowania regionalne i międzynarodowe, red. R. Fiedler, T. Wallas, Fundacja na Rzecz Czystej Energii, Poznań.

Özalp O. N. (2011), Avrupa Birliği'nin Orta Asya Politikası, „Civil Academy”, Winter.

Peyrouse S. (2014), How does Central Asia view the EU, "EUCAM Working Paper, no. 18.

Pohl A. (2016), Bezpieczeństwo gazowe Unii Europejskiej a potencjat państw Azji Centralnej, w: Unia Europejska wobec Azji Centralnej - uwarunkowania regionalne i międzynarodowe, red. R. Fiedler, T. Wallas, Fundacja na Rzecz Czystej Energii, Poznań.

Pomfret R. (2006), The Central Asian Economies Since Independence, Princeton.

Przybylska-Maszner B. (2016), Uwarunkowania ksztaltowania priorytetów polityki zagranicznej Unii Europejskiej wobec państw Azji Centralnej po roku 2012, „Rocznik Integracji Europejskiej", nr 10.

Regional Strategy Paper for Assistance to Central Asia for the Period 2007-2013 (2007), http://eeas. europa.eu/archives/docs/central_asia/rsp/07_13_en.pdf.

Walkowski M. (2016), Między Chińska Republika Ludowa a Federacją Rosyjska. Dylematy rozwoju społeczno-ekonomicznego państw Azji Centralnej, w: Unia Europejska wobec Azji Centralnej-uwarunkowania regionalne i międzynarodowe, red. R. Fiedler, T. Wallas, Fundacja na Rzecz Czystej Energii, Poznań.

Wallas T. (2016), Uwarunkowania regionalne i międzynarodowe w kontekście polityki Unii Europejskiej wobec Azji Centralnej, w: Unia Europejska wobec Azji Centralnej - uwarunkowania 
regionalne i międzynarodowe, red. R. Fiedler, T. Wallas, Fundacja na Rzecz Czystej Energii, Poznań.

Warkotsch A. (2011), The European Union and Central Asia, London, New York.

Zhao L. (2006), Central Asia Political Development after the Colour Revolution, "International Social Science Journal".

\section{Streszczenie}

Dla Unii Europejskiej kryzys w stosunkach z Turcją może mieć swoje wielorakie konsekwencje, a waga wzajemnych relacji najprawdopodobniej przyczyni się do wypracowania w najbliższej przyszłości nowego modelu instytucjonalnej i przedmiotowej współpracy obu podmiotów. Taki stan rzeczy otwartym czyni pytanie o to czy stosunki Unii Europejskiej z państwami Azji Centralnej zyskają nową dynamikę? Tym samym celem niniejszego artykułu jest rozstrzygnięcie kwestii czy spadek znaczenia Turcji jako partnera dla Wspólnoty przełoży się na automatyczny wzrost znaczenia wspomnianego regionu świata dla Unii Europejskiej.

Słowa kluczowe: Azja Centralna, Unia Europejska, Turcja, strategia, bezpieczeństwo

\section{European Union's inks with the states of Central Asia facing a crisis in the Turkish-EU relations}

\section{Summary}

The crisis in the Turkey's relation with EU might have many consequences however an overall importance of bilateral relation will soon contribute to creation of new institutional cooperation model. This opens a question if European Union's relation with Central Asian states will gain a new impetus? Thus this paper aims to answer the question if the diminishing of Turkey's role in Europe will automatically make EU's relations with Central Asia the key ones from the Brussels' perspective.

Key words: Central Asia, European Union, Turkey, strategy, security 